\title{
Utilizando o Lúdico no Processo de Educar em Saúde: Produzindo Jogos Educativos para Crianças e Adolescentes
}

\author{
Melo, Luciana de Lione \\ Universidade Estadual de Campinas - Unicamp - lulione@fcm.unicamp.br
}

Introdução: o jogo é considerado como uma das principais premissas básicas do ser humano. no jogo existe alguma coisa 'em jogo' que transcende as necessidades imediatas da vida e confere sentido à ação. Considerando que educar é ir além da transferência de conhecimentos, mas, sobretudo possibilitar sua produção, a utilização do jogo desperta a ideia de um ensino com ênfase nas necessidades do aluno, onde o professor se coloca como um gerador de situações estimulantes eficazes. Assim como é possível utilizar jogos na educação formal de adultos, também o é no processo de educar em saúde. a preocupação por esta temática reflete a mudança de paradigma em relação às práticas de saúde, antes fragmentadas e curativas e, atualmente, vistas numa concepção de assistência integral e inseridas no contexto da promoção à saúde. Assim, a utilização dos jogos educativos no processo de educação em saúde é capaz de, por um lado colaborar na formação do aluno de graduação em enfermagem ensinando-o estratégias alternativas de educação e, por outro lado, beneficiar os jogadores, crianças e adolescentes, a aprender sobre saúde. Objetivo: Apresentar a produção de jogos educativos para educação em saúde em enfermagem pediátrica. Métodos: Trata-se de um relato de experiência como parte da estratégia de ensino-aprendizagem da disciplina Assistência de Enfermagem na Saúde da Criança e do Adolescente I do curso de graduação em Enfermagem da Unicamp. Resultados: Foram produzidos, desde 2005, 11 jogos educativos, para dois a seis jogadores, além de um adulto mediador. São eles Aprendendo sobre o Corpo Humano, Pandemia, Questão de Saúde, Crescendo e Aprendendo, Paradigma, Aprenda sobre o nosso corpo brincando, o "X" da Saúde, Saúde em Jogo, Jogo do Mico, Imagem e Mensagem, Tá na Mesa Pessoal!, Reciclando - uma maneira divertida de aprender a salvar o mundo, Caixa Mágica, Figura e ação, Amarelinha Saudável, Escobanho, Montando o seu corpo, Fases da vida e Corrida pela Saúde. Após a confecção, os jogos educativos foram utilizados para educação em saúde com crianças e adolescentes em unidades básicas de saúde, creches, ambulatórios e hospitais. Conclusões: Os jogos educativos demonstraram ser uma estratégia de baixo custo, efetiva para lidar com a faixa etária escolhida, independente do tema abordado. a ação imposta pelo jogo exige uma postura ativa dos jogadores, que, ao jogar, articulam o ensino e a aprendizagem em um único movimento. Além disso, o confeccionar os referidos jogos, para os alunos de graduação em enfermagem, possibilitou uma visão do que é essencial para o cuidado em enfermagem pediátrica - conhecimento científico capaz de transcender o cuidado técnico, possibilitando que se vislumbre o cuidado sensível em busca da humanização em saúde.

Melo, Luciana de Lione. Utilizando o Lúdico no Processo de Educar em Saúde: Produzindo Jogos Educativos para Crianças e Adolescentes. In: Anais do Congresso Internacional de Humanidades \& Humanização em Saúde [= Blucher Medical Proceedings, num.2, vol.1]. São Paulo: Editora Blucher, 2014. ISSN 2357-7282 DOI $10.5151 /$ medpro-cihhs-10300 